\title{
FAKTOR-FAKTOR YANG MEMPENGARUHI PERILAKU WORD OF MOUTH INTENTION PELANGGAN PADA TEMPAT MAKAN MASAKAN KHAS JAWA DI SURABAYA
}

\author{
Nurfathan Hasbiy Purwanto ${ }^{1}$ \\ Departemen Manajemen Layanan dan Pariwisata, Universitas Surabaya, Surabaya, Indonesia, \\ ernajani@staff.ubaya.ac.id
}

\begin{abstract}
Siti Rahayu2
Departemen Manajemen Layanan dan Pariwisata, Universitas Surabaya, Surabaya, Indonesia, ernajani@staff.ubaya.ac.id

Erna Andajani ${ }^{3}$

Departemen Manajemen Layanan dan Pariwisata, Universitas Surabaya, Surabaya, Indonesia, ernajani@staff.ubaya.ac.id
\end{abstract}

\begin{abstract}
Background - The restaurant industry is a very competitive industry to attract and retain consumers. Restaurant owners need to understand how consumers want, need and perceptions. Word of mouth (WOM) has an important role in any effective marketing strategy for the restaurant industry.
\end{abstract}

Purpose - This study aims to determine the influence of food quality,

Diterima : 03 September 2020

Direview : 13 Oktober 2020

Direvisi : 20 Oktober 2020

Disetuiui : 24 Januari 2021 the quality of personal interaction, the quality of the physical environment, the perceived value, and the quality of the relationship (satisfaction, trust, and commitment) on the behavior of mouth-to-mouth intention of customers where to eat Javanese specialties in Surabaya.

Design / Methodology / Approach - This study uses a sample of 200 respondents. The data processing method used in this research is Structural Equation Modeling (SEM) with LISREL 8.8 for Window software. The target population in this study is all people who have eaten and drank in one of the 10 places to eat Javanese specialties in Surabaya. The type of sampling in this study is accidental sampling or convenience sampling.

Result and Discussion - Food quality, physical environment, personal interactional quality, perceived value have a significant positive effect on satisfaction. Satisfaction has a significant positive effect on Word of Mouth and trust. Satisfaction does not have an impact on the customer commitment to eating Javanese specialties in Surabaya. Trust has a significant positive effect on the customers' commitment to eating Javanese specialties in Surabaya. Trust and commitment have no influence on the word of mouth intention of customers to eat Javanese specialties in Surabaya.

Conclusion - The results of the study found that customers of Javanese cuisine in Surabaya rated satisfaction as not the main assessment in forming a commitment to return to enjoy the food served. Business actors need to find and develop new things from other aspects such as beautifying interior and exterior buildings or increasing the variety of food and improving services and small things such as cleanliness. In the restaurant business, it is necessary to develop more value which is not owned by competitors. This makes it difficult for customers to find other alternatives.

Researh Limitations - In this study, it was found that the Commitment variable alone was not sufficient in measuring the relationship between commitment and word of mouth intention, researchers needed to measure the commitment variable into three parts, namely affective commitment, calculative commitment and normative commitment. By measuring the commitment dimension, further research is expected to see how the results of the impact of the commitment dimension on word of mouth intention in the service industry.

Keyword : Satisfaction, Trust, Commitment, Word of Mouth, Intentions 


\begin{abstract}
ABSTRAK
Latar Belakang - Industri restoran merupakan industri yang sangat kompetitif, untuk menarik dan mempertahankan konsumen maka pemilik restoran perlu memahami bagaimana keinginan, kebutuhan dan persepsi konsumen. Word of Mouth (WOM) memiliki peran penting dalam setiap strategi pemasaran yang efektif untuk industri restoran.
\end{abstract}

Tujuan - Penelitian ini bertujuan untuk mengetahui pengaruh variabel kualitas makanan, kualitas interaksi personal, kualitas lingkungan fisik, nilai yang dirasakan, dan kualitas hubungan (kepuasan, kepercayaan, dan komitmen) terhadap perilaku mulut. Niat mulut-ke-mulut pelanggan tempat makan makanan khas Jawa di Surabaya..

Desain / Metodologi / Pendekatan - Penelitian ini menggunakan sampel 200 responden. Metode pengolahan data yang digunakan dalam penelitian ini adalah Structural Equation Modeling (SEM) dengan software LISREL 8.8 for Window. Populasi sasaran dalam penelitian ini adalah seluruh masyarakat yang pernah makan dan minum di salah satu dari 10 tempat makan makanan khas Jawa yang ada di Surabaya. Jenis pengambilan sampel dalam penelitian ini adalah accidental sampling atau convenience sampling.

Hasil dan Pembahasan - Kualitas makanan, lingkungan fisik, kualitas interaksi pribadi, nilai yang dirasakan berpengaruh positif signifikan terhadap kepuasan. Kepuasan berpengaruh positif signifikan terhadap Word of Mouth dan kepercayaan. Kepuasan tidak berdampak pada komitmen pelanggan untuk menyantap makanan khas Jawa di Surabaya. Kepercayaan berpengaruh positif signifikan terhadap komitmen konsumen terhadap makanan khas Jawa di Surabaya. Kepercayaan dan komitmen tidak berpengaruh terhadap niat mulut ke mulut pelanggan untuk menyantap makanan khas Jawa di Surabaya.

Kesimpulan - Hasil penelitian menemukan bahwa pelanggan kuliner Jawa di Surabaya menilai kepuasan bukan penilaian utama dalam membentuk komitmen untuk kembali menikmati makanan yang disajikan. Pelaku usaha perlu mencari dan mengembangkan hal-hal baru dari aspek lain seperti mempercantik interior dan eksterior bangunan atau memperbanyak variasi makanan serta meningkatkan pelayanan dan hal-hal kecil seperti kebersihan. Dalam bisnis restoran perlu dikembangkan nilai lebih yang tidak dimiliki pesaing. Hal ini menyulitkan pelanggan untuk mencari alternatif lain.

Batasan Penelitian - Pada penelitian ini ditemukan bahwa variabel Commitment saja tidak cukup dalam mengukur hubungan antara Commitment dan Word of mouth intention, peneliti perlu mengukur variabel Commitment menjadi tiga bagian yaitu Affective commitment, Calculative commitment dan Normative commitment. Dengan mengukur dimensi commitment ini penelitian selanjutnya diharapkan bisa melihat bagaimana hasil dari pengaruh dimensi commitment terhadap Word of mouth intention di industri layanan.

Kata Kunci : Kepuasan, Kepercayaan, Komitmen, Intensitas, Word of Mouth.

\section{PENDAHULUAN}

Industri restoran merupakan industri yang sangat kompetitif, untuk menarik minat dan mempertahankan konsumen, pemilik restoran perlu memahami bagaimana keinginan, kebutuhan serta persepsi konsumen. word of mouth (WOM) memiliki peranan penting dari setiap strategi pemasaran yang efektik untuk industri restoran. Restoran dengan anggaran promosi terbatas sangat bergantung pada media promosi word of mouth, oleh karena itu, WOM dapat dianggap sebagai sarana penting untuk menarik minat serta mempertahaknan konsumen (Wirtz dan Chew, 2002). Baloglu dan Mccleary (1999) 
dalam Jalilvand et al., (2017) berpendapat word of mouth memiliki dampak paling positif terhadap citra yang dirasakan konsumen dari pada tiga lainnya yaitu, saran dari professional, iklan, buku, film, dan berita. Selain itu terdapat penelitian yang menunujukkan bahwa $76 \%$ dari semua keputusan pembelian dipengaruhi oleh word of mouth dan diperkirakan terdapat 3,4 Miliar percakapan word of mouth setiap harinya dan 2,3 Miliar diantaranya adalah percakapan yang membahas sebuah merek.

Penelitian yang dilakukan oleh Nielsen melalui studinya menjelaskan bahwa 59\% pelanggan di Indonesia lebih suka memilih hindangan makanan khas lokal. Serta pada wilayah Asia tenggara ditemukan bahwa tindakan dapat melebihi kepercayaan pada 19 format iklan yang telah disurvei, dimana responden yang mempercayai rekomendasi dari orang yang dikenal mengaku bahwa keputusan atau tindakan pembelian didasari oleh pendapat atau rekomendasi dari orangorang yang dikenal dengan nilai 91\% tindakan (take action) dan 88\% kepercayaan (trust), sementara itu iklan-iklan di TV dan situs bermerek masing-masing memiliki persentase sebesar $81 \%$.

\section{TINJAUAN PUSTAKA}

Menurut Namkung dan Jang (2007) bahwa kualitas makanan merupakan syarat yang diperlukan untuk memenuhi kebutuhan dan harapan pelanggan. Kualitas makanan merupakan konsep yang terpenting dalam menciptakan suatu produk.

Lemke et al., 2011 dalam Choi dan Kim (2012) menyatakan bahwa Personal interaction quality merupakan hubungan intreraksi interaktif antara pelanggan dengan pemberi layanan, dimana karyawan dan staff sebagai perwakilan perusahaan tersebut, yang akan berkomunikasi secara langsung dengan pelanggan mulai dari proses pemberian informasi sampai proses layanan diberikan.

Menurut Mowen dan Minor (2002) berpendapat Aspek fisik dan tempat dari lingkungan fisik dapat mempengaruhi perilaku dari pelanggan. seperti warna, suara, penerangan, dan susunan tatanan ruang, orang atau benda. Lingkungan fisik dapat mempengaruhi persepsi konsumen dengan cara mekanisme melalui inrdra penglihatan, pendengaran, penciuman, dan indra sentuhan atau peraba.

Menurut Zeithaml (1998) dalam Ryu et al., (2012), nilai yang dirasakan oleh pelanggan dapat diartikan sebagai hasil perbandingan antara manfaat yang dirasakan secara dengan pengorbanan yang dirasakan atau biaya yang dibayar oleh pelanggan. Parasuraman et al., (1995) dalam Ryu et al., (2012) Berpendapat pelanggan dapat mengevaluasi sebuah produk atau layanan yang telah dibeli dapat. menyediakan nilai dan harapan yang sesuai, sehingga hasil dari evaluasi nilai yang 
diberikan oleh pelanggan bersifat subjektif dan pribadi.

Huntley (2006) dalam jalivand et al., (2017), menyatakan bahwa Relationship Quality sebagai tingkat kepuasan pembeli dari waktu ke waktu dengan kemitraan keseluruhan, diwujudkan dalam kualitas produk, kualitas layanan dan nilai uang.

Deng et al., (2009) dalam Jalivand et al., (2017) berpendapat Karena kepuasan adalah keadaan emosional, reaksi pasca-pembelian dapat berupa kemarahan, ketidakpuasan, kejengkelan, netralitas, kegembiraan, atau kesenangan. Selain itu kupuasan pelanggan merupakan bentuk evaluasi pelanggan terhadap produk dan layanan dalam hal apakah sudah sesuai dengan persyaratan pelanggan tersebut.

Morgan dan Hunt (1994) dalam Jalivand et al., (2017) berargumen kepercayaan didefinisikan sebagai satu orang percaya bahwa orang lain akan memenuhi kebutuhannya. Dalam hal layanan, kepercayaan merupakan pendapat yang dipegang oleh pelanggan bahwa penyedia layanan akan menyediakan layanan yang dapat memenuhi kebutuhan pelanggan.

Menurut Moorman et al., (1992) mendefinisikan komitmen sebagai hasrat abadi untuk mempertahankan hubungan yang berharga, dari definisi ini dapat diketahui jika komitmen tidak dapat melibatkan hanya satu pihak saja. Komitmen akan memotivasi dari kedua belah pihak untuk membangun hubungan kerjasama yang lebih baik dan meyakinkan.

Menurut Kotler and Keller (2012) word of mouth marketing adalah kegiatan pemasaran melalui perantara orang ke orang baik secara lisan, tulisan, maupun alat komunikasi elektronik berhubungan dengan pengalaman pembelian jasa atau dalam penggunaannya.

\section{Hipotesis}

Law et al., (2004) dalam Namin (2016) berpendapat bahwa "... food quality and the various food offered are an important elemet og customer satisfaction". Dimana pada hal ini menunjukkan food quality serta berbagai macam makanan yang ditawarkan merupakan unsur penting dari kepuasan pelanggan. Selain itu Yuksel (2002) dalam Jalivand et al., (2017) menegaskan jika pelanggan cenderung menghabiskan uang dan waktu di lingkungan layanan yang dapat memicu perasaan senang. Atribut restoran seperti kualitas makanan dan tema merupakan hal yang penting dalam mendapatkan kepuasan pelanggan. Pada penelitian ini dapat ditarik pernyataan sebagai berikut.

\section{H1: Food quality berpengaruh positif terhadap Satisfaction pelanggan restoran makanan khas jawa di Surabaya}

Gabarino dan Johnson (1999) dalam Jalivand et al., (2017) berpendapat bahwa kepuasan pelanggan dalam industri restoran dapat dipengaruhi oleh kualitas dari lingkungan fisik restoran. Selain itu Chang 
(2000) dalam Ryu dan Han (2009) mengemukakan bahwa kualitas lingkungan fisik yang dipersepsikan merupakan indikator langsung dari kepuasan pelanggan. Wakefield dan Blodgett (1996) dalam Ryu dan Han (2009) mengungkapkan bahwa persepsi akan kualitas lingkungan fisik secara signifikan mempengaruhi kepuasan pelanggan. Pada penelitian ini dapat ditarik pernyataan sebagai berikut.

\section{H2: Physical environment quality} berpengaruh positif terhadap Satisfaction pelanggan restoran makanan khas jawa di

\section{Surabaya}

Menurut Getty dan Thompson (1994) dalam Jalivand et al., (2017) menunjukkan bahwa tingkat kepuasan yang tinggi dapat meningkatkan niat pelanggan untuk membeli kembali serta niat untuk merekomendasikan produk dan layana. Pelanggan yang merasa puas serta dapat menyebarkan WOM secara positif maka secara tidak langsung pelanggan tersebut membantu perusahaan dalam menyediakan iklan secara gratis yang di sebut dengan word of mouth (Jalivand dan Samiei, 2012 dalam Jalivand et al., 2017). Pada penelitian ini dapat ditarik pernyataan sebagai berikut.

H3: Satisfaction berpengaruh positif terhadap word of mouth intention pelanggan restoran makanan khas jawa di

\section{Surabaya}

Fang et al., (2011) menyatakan bahwa semakin baik kualitas interaksi personal dengan perusahaan maka semakin tinggi kepuasan konsumen terhadap produk atau layanan yang dimiliki perusahaan. Selain itu Jamel dan Naser (2002) dalam Choi dan Kim (2012) menyatakan kualitas relasional, mengacu pada kualitas interaksi antara karyawan dengan pelanggan, memiliki pengaruh langsung pada kepuasan pelanggan. Choi dan Kim (2012) memberi saran untuk meningkatkan relationship quality perlu upaya untuk menjamin personal interaction quality yang baik dengan pelanggan. Pada penelitian ini dapat ditarik pernyataan sebagai berikut.

H4: Personal interaction quality berpengaruh positif terhadap Satisfaction pelanggan restoran makanan khas jawa di Surabaya

Patterson dan Spreng (1997) dalam Ryu et al., (2012) menyatakan nilai yang dirasakan pelanggan memiliki hubungan positif dan langsung dengan kepuasan pelanggan. McDougall dan Levesque (2000) dalam Ryu et al., (2012) berpendapat bahwa persepsi terhadap kualitas layanan dan nilai yang dirasakan pelanggan merupakan dua indikator kepuasan pelanggan yang paling menonjol di empat industri jasa yaitu, restoran, layanan otomatis, penata rambut, dan layanan gigi. Pada penelitian ini dapat ditarik pernyataan sebagai berikut.

H5: Perceived value berpengaruh positif terhadap satisfaction pelanggan restoran makanan khas jawa di Surabaya 
Walsh et al., (2010) dalam Jalivand et al., (2017), dalam pasar ritel secara online dan offline kepuasan memiliki dampak positif terhadap kepercayaan dan komitmen konsumen. Chien-Lung Hsu et al., (2010) dalam Purnasari dan Yuliando (2015) berpendapat "Customers satisfaction with enterprises has a positive influence on customers trust”, artinya kepuasan pelanggan dengan perusahaan memiliki pengaruh positif pada kepercayaan pelanggan. Pada penelitian ini dapat ditarik pernyataan sebagai berikut.

H6: Satisfaction berpengaruh positif terhadap Trust pelanggan restoran makanan khas jawa di Surabaya

H7: Satisfaction berpengaruh positif terhadap Commitment pelanggan restoran makanan khas jawa di Surabaya

Kepercayaan lebih didasarkan pada proses sosial yang terjadi dalam hubungan bisnis, sementara komitmen lebih berorientasi pada rencana berhubungan satu sama lain di masa depan. Trust dan commitment merupakan hasil dari pengembagnan hubungan kolaboratif antara dua perusahaan. Mengembangkan sebuah hubungan bisnis yang dapat dipercaya membutuhkan proses jangka panjang, yang berlangsung tahap demi tahap, risiko, dan ketidak menentuan berkurang, sedangkan commitment dan trust meningkat (Zineldin et al., 1997). Pada penelitian ini dapat ditarik pernyataan sebagai berikut.
H8: Trust berpengaruh positif terhadap commitment pelanggan restoran makanan khas jawa di Surabaya

Menurut Baloglu (2002) dalam Jalivand et al., (2017) menyatakan bahwa pelanggan setia memiliki ikatan yang kuat serta komitmen yang kuat. Pelanggan dapat menciptakan WOM positif serta persepsi terhadap harga dapat berkurang. Geyskens et al., (1996), singh dan Sirdeshmukh (2000) dalam Ribbink et al., (2004) menjelaskan bahwa kepercayaan sangat memiliki pengaruh terhadap hubungan antara restoran dengan pelanggannya dan juga dapat mempengaruhi perilaku dari pelanggannya di waktu yang akan datang. Moorman et al., (1992) menyatakan bahwa sebuah komitmen membuat keberhasilan dalam berhubungan, serta hubungan antara mitra bisa saling menguntungkan satu dengan yang lain dan puas. Komitmen yang muncul dari pelanggan membuat mereka konsisten dalam mengunjungi restoran serta loyalitas pelanggan dapat memberikan rekomendasi kepada orang lain. Pada penelitian ini dapat ditarik pernyataan sebagai berikut.

H9: Trust berpengaruh positif terhadap word of mouth intention pelanggan restoran makanan khas jawa di Surabaya H10: Commitment berpengaruh positif terhadap word of mouth intention pelanggan restoran makanan khas jawa di Surabaya. 


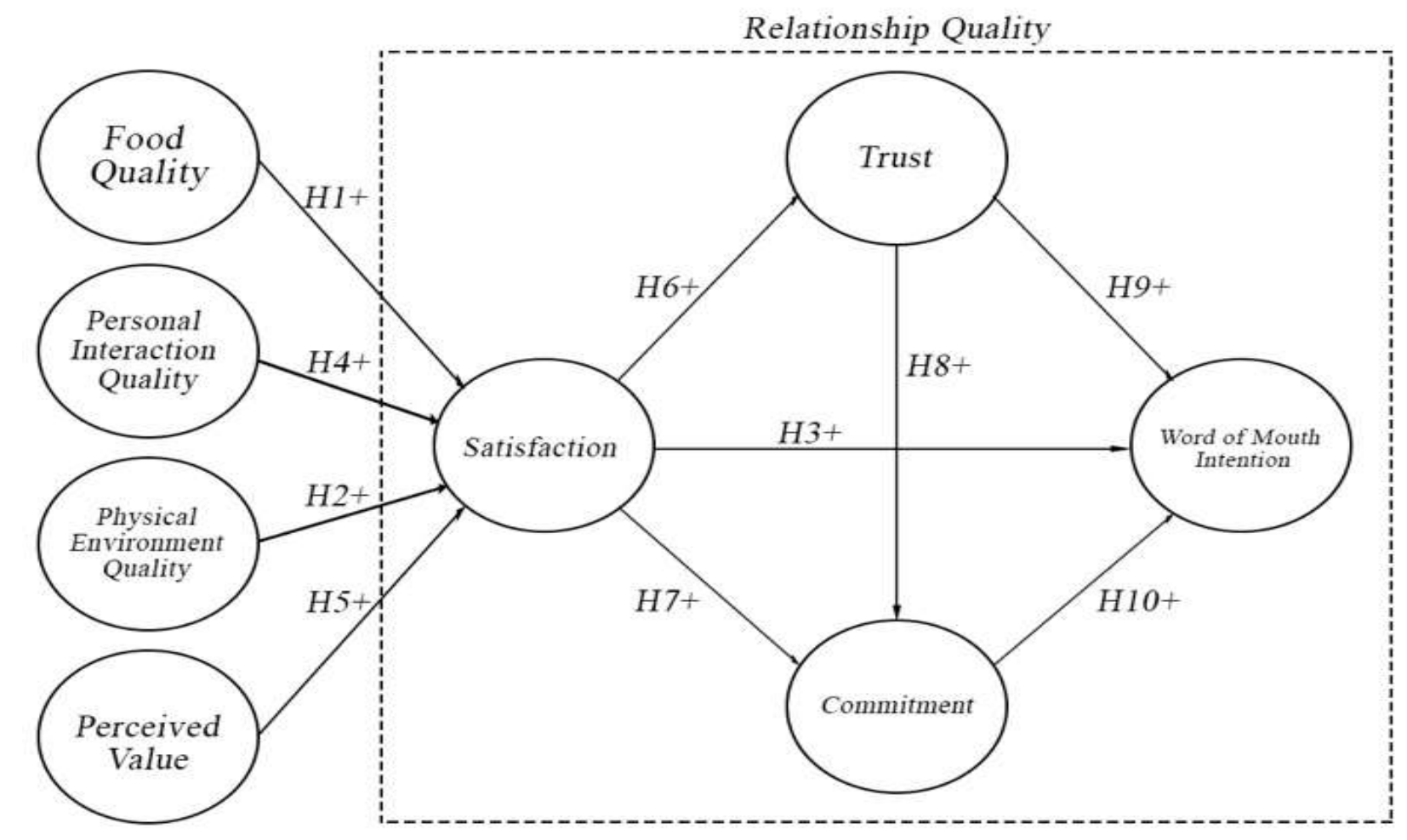

Sumber: Jalivand et al., (2017).

Gambar 1. Model Penelitian

\section{METODOLOGI PENELITIAN}

Aras dan skala yang digunakan pada penelitian ini merupakan aras interval, yaitu aras pengukuran yang memiliki jarak yang sama dan selisih yag sama pada skala pengukuran (Trimudi dan Harini, 2008). aras interval disusun berdasarkan numerical scale yaitu 5 point likert scale yang digunakan untuk memberikan penilaian kepada masing-masing pernyataan. Semakin besar nilai yang mendekati angka 5 maka menunjukkan tanggapan positif atau setuju terhadap pernyataan dalam kuesioner, namun apabila semakin kecil nilai yang mendekati angka 1 maka menunjukkan tanggapan yang negatif atau tidak setuju dengan pernyataan yang ada dalam kuesioner tersebut. Besaran jumlah sampel pada penelitian ditujukan berdasarkan kecukupan teknik analisis yang digunakan merupakan metode maximum likehood. Menurut Wijanto (2008), ukuran sampel yang diperlukan untuk metode estimasi maximum likehood adalah 5 dan maksimal 10 responden untuk jumlah variabel teramati (indikator) yang ada pada model.

Dalam penelitian ini jumlah variabel teramati (indikator) adalah 31. Maka jumlah sampel yang digunakan minimal 5 dikalikan 31 indikator yaitu sebanyak 155 responden dan maksimal adalah 10 dikalikan 31 yaitu sebanyak 310 responden. Namun menurut Merdsker et al., (1994) dalam Jalivand et al., (2017) merekomendasikan agar besaran 
sampel tidak lebih dari 200 responden, maka dari itu penelitian ini menggunakan sampel sebesar 200 responden.

Metode pengolahan data yang digunakan dalam penelitian ini adalah Structural Equation Modeling (SEM) dengan software LISREL 8.8 for Windows. Syarat jumlah good fit index menurut Hair et al., (2010) yang baik kurang lebih menggunakan paling tidak 3-4 indeks dari indeks absolute dan incremental agar dapat dilakukan pengujian lanjutan model penelitian. Terdapat beberapa indeks kesesuaian (absolute dan incremental) untuk menguju model diterima atau ditolak, Uji Validitas merupakan sejauh mana sebuah pengukuran/ sekumpulan pengukuran dapat mengukur secara akurat konsep yang diteliti (Hair et al., 2010). Cara yang digunakan untuk mengukur validitas dan realibilitas adalah dengan menggunkan bantuan program computer SPSS 25 for windows untuk mengevaluasi apakah instrument penelitian kuesioner sudah tepat digunakan untuk mengukur variabel penelitian.

Target populasi dalam penelitian ini adalah semua orang yang pernah makan dan minum di salah satu 10 tempat makan masakan khas Jawa di Surabaya yaitu: (1) Lontong Balap Garuda pak Gendut, (2) Sate Klopo Ondomohen bu Asih, (3) Soto Ayam Lamongan Cak Har, (4) Soto Ambengan Pak Sadi, (5) Tahu Telur Pak Jayen, (6) Pecel Ponorogo bu Yatin, (7) Pecel Madiun Bu Kus,
(8) Bebek Palupi (J1. Raya Rungkut Asri Tengah), (9) Rawon Setan (J1. Embong Malang), (10) Rujak Cingur Ahmad Jais, dengan karakteristik sebagai berikut:

1. Berdomisili di Surabaya.

2. Berusia minimal 17 tahun.

3. Pernah berkunjung, makan dan minum di salah satu dari 10 tempat makan masakan khas Jawa di Surabaya, sebanyak 2 kali dalam 6 bulan terakhir.

4. Apabila responden pernah berkunjung ke semua objek yang ditentukan maka responden wajib memilih salah satu objek yang terakhir kali dikunjungi.

5. Memiliki pendidikan minimal SMA/SMK/Sederajat dengan tujuan responden mampu memahami dan menjawab pernyataan yang ada pada kuesioner secara objektif mengenai Food quality, physical environment quality, personal interaction quality dan perceived value, Satisfaction, Trust, Commitment dan Word of Mouth Intention.

6. Pernah memberikan rekomendasi kepada orang lain mengenai salah satu dari 10 tempat makan masakan khas Jawa di Surabaya.

Teknik pengambilan sampling yang digunakan pada penelitian ini adalah nonprobability sampling, merupakan teknik pengambilan sampel dimana setiap anggota dari populasi tidak memiliki peluang yang sama untuk menjadi sampel atau subjek penelitian (sekaran and bougie, 2010). Serta 
populasi yang akan diambil tidak bisa teridentifikasi dengan jelas berapa jumlah keseluruahnnya. Jenis pengambilan sampel dalan penelitian ini merupakan accidental sampling atau convencience sampling yakni teknik penentuan sampel berdasarkan kebetulan, yaitu siapa saja yang secara kebetulan bertemu dengan peneliti dapat digunakan sebagai sampel, jika orang yang ditemui tersebut cocok sebagai sumber data (Sugiyono, 2013).

\section{HASIL DAN PEMBAHASAN}

Model struktural yang akan diteliti yaitu mengenai pengaruh dari variabel food quality, physical environment quality, personal interaction quality, perceived value, satisfaction, trust, commitment, terhadap word of mouth intention dari pelanggan restoran makanan khas Jawa yang ada di Surabaya. Pada penelitian ini model struktural dianalisis melalui aplikasi program LISREL 8.8 for Windows.
Berdasarkan hasil pada tabel 1 dapat diketahui hasil uji kecocokan struktural model sudah menunjukkan kriteria yang baik dimana ukuran nilai kecocokan telah memenuhi kriteria yang ditetapkan. Dimana pada hasil tersebut nilai CMIN/DF (1.485), RMSEA (0.049), TLI/NNFI (0.96), CFI (0.96) dimana hasil tersebut termasuk kategori good Fit, dan nilai GFI (0.84) termasuk dalam kategori majinal fit (mendekati), dengan demikian untuk malakukan uji hipotesis dapat menggunakan hasil uji kecocokan model struktural yang sudah ada. Setelah proses pengujian yang telah dilaksanakan maka uji hipotesis dapat dilakukan, dimana pada uji hipotesis ini menggunakan software Lisrel 8.8, sesuai dengan teori acuan dimana besaran nilai T-value memiliki nilai mutlak 1,96, sehinggan batasan nilai hipotesis dapat diterima atau ditolak apabila nilai T-value lebih besar dari 1,96.

Tabel 1

Uji Goodness of Fit Struktural Model

\begin{tabular}{l|l|r|l} 
Uji Kecocokan & \multicolumn{1}{|c}{ Kriteria } & Hasil & \multicolumn{1}{|c}{ Ket. } \\
CMIN/DF & CMIN/DF $\leq 2$ & 1.485 & Good Fit \\
RMSEA & RMSEA $\leq 0.08$ & 0.049 & Good Fit \\
GFI & $\geq 0.90$ & 0.84 & Marjinal Fit \\
TLI/ NNFI & $\geq 0.90$ & 0.96 & Good Fit \\
CFI & $\geq 0.90$ & 0.96 & Good Fit
\end{tabular}

Sumber : Data Diolah, 2020 
Tabel 2

Hasil Uji Hipotesis

\begin{tabular}{clrrl} 
& \multicolumn{1}{c}{ Hipotesis } & T-Value & Std.Est & Ket \\
H1 & Food Quality $\rightarrow$ Satisfaction & 3.38 & 0.29 & Terdukung \\
H2 & Phsical Environment Quality $\rightarrow$ Satisfaction & 3.85 & 0.33 & Terdukung \\
H3 & Satisfaction $\rightarrow$ Word of Mouth & 3.25 & 0.53 & Terdukung \\
H4 & Personal Interction Quality $\rightarrow$ Satisfaction & 3.97 & 0.32 & Terdukung \\
H5 & Percieved Value $\rightarrow$ Satisfaction & 3.06 & 0.22 & Terdukung \\
H6 & Satisfaction $\rightarrow$ Trust & 6.48 & 0.78 & Terdukung \\
H7 & Satisfaction $\rightarrow$ Commitment & 0.70 & 0.12 & Tidak Terdukung \\
H8 & Tust $\rightarrow$ Cmmitment & 3.52 & 0.68 & Terdukung \\
H9 & Trust $\rightarrow$ Word of Mouth & 0.93 & 0.93 & Tidak Terdukung \\
H10 & Commitment $\rightarrow$ Word of Mouth & 0.80 & 0.12 & Tidak Terdukung \\
\hline
\end{tabular}

Sumber : Data Diolah, 2020

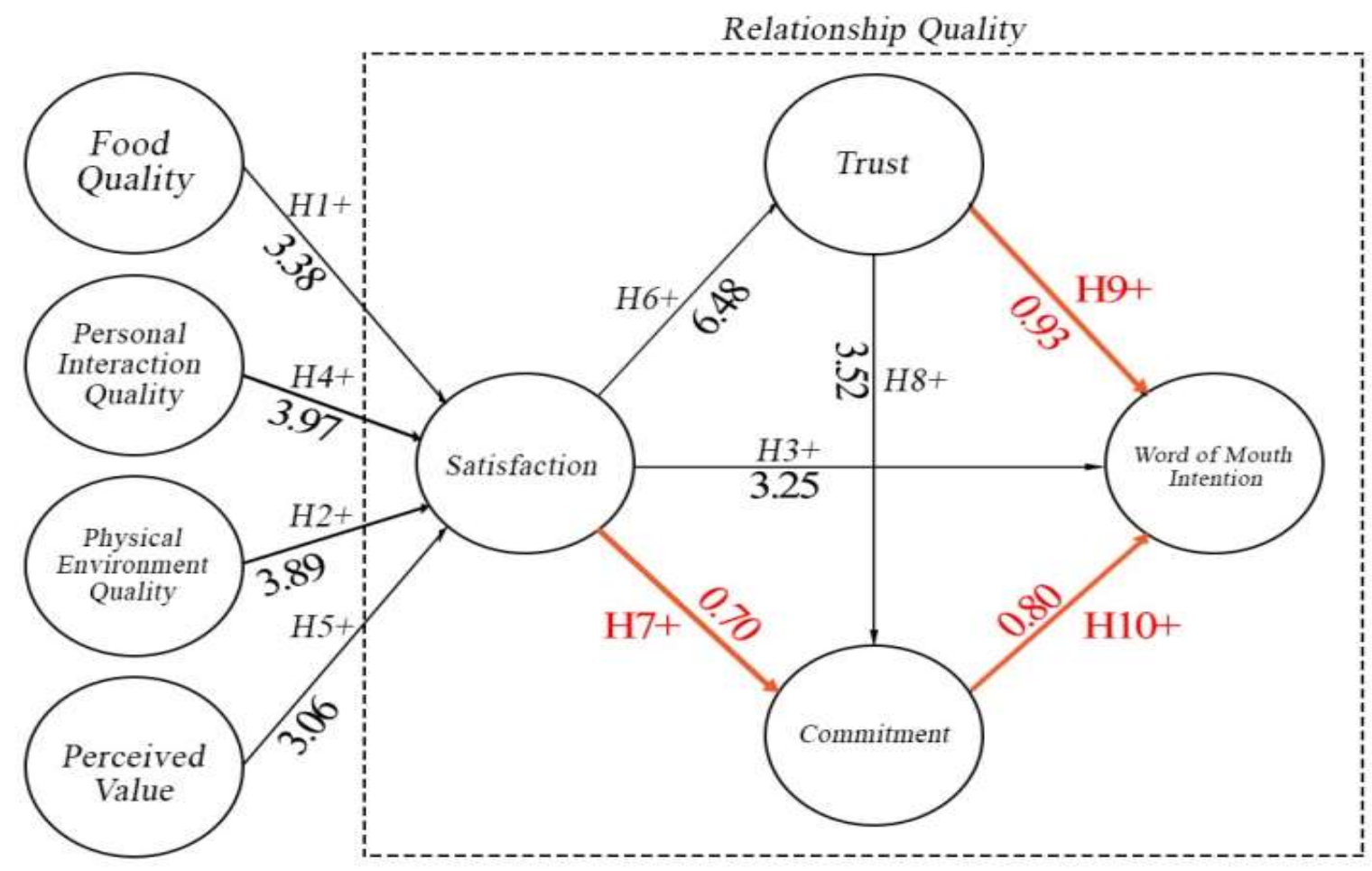

Gambar 2. Value pada tiap hipotesa penelitian

Berdasarkan hasil dari penelitian ini ditemukan beberapa kesamaan hasil dari penelitian sebelumnya yang dilakukan oleh Jalivand et al., (2017), yaitu variabel Food quality, Physical environment quality, Personal interaction quality dan Perceived value memiliki pengaruh terhadap variabel satisfaction.

Dimana pada hal ini jika semua indikator-indikator yang terdapat pada setiap variabel seperti salah satunya restoran makanan khas jawa menyajikan makanan yang hangat dan memiliki rasa 
yang enak yang terdapat pada variabel Food quality, restoran makanan khas jawa memiliki peralatan makanan yang bersih serta menyediakan area makan yang nyaman yang terdapat variabel Physical environment quality, pelayan dapat memperlakukan pelanggan dengan ramah yang terdapat pada variabel Personal interaction quality, dan harga makanan yang ditawarkan sesuai dengan kualitas yang terdapat pada variabel Perceived value. Maka memungkingkan kepuasan (satisfaction) pelanggan dapat terpenuhi.

Bitner dan Hubbert (1994) dalam Jalivand et al., (2017) pada konseptual dan pengembangan hipotesis menyatakan bahwa kualitas makanan (food quality) memiliki hubungan langsung dengan kepuasan pelanggan (customer satisfaction), dimana pada hal ini merupakan faktor inti untuk memenuhi kebutuhan pelanggan. Selain itu Teng dan Chang (2013) dalam Jalivand et al., (2017) menyebutkan bahwa rasa, pilihan makanan yang sehat, penyajian makanan, kesegaran bahan makanan, variasi menu makanan, dan suhu makanan saat disajikan merupakan faktor penting dalam kualitas makanan (food quality).

Temuan dalam penelitian yang dilakukan Jalivand et al., (2017) menyatakan bahwa kualitas lingkungan fisik serperti dekorasi yang menarik, musik, warna serta pencahayaan lingkungan restoran dapat meningkatkan kepuasan pelanggan yang berkunjung. Pernyataan ini juga sesuai dengan hasil penelitian yang dilakukan Ryu dan Han (2009) dimana ketika pelanggan merasakan bahwa lingkungan fisik dapat mencerminkan sebuah kualitas yang baik seperti dekorasi yang menarik dan pencahayan yang baik maka tingkat kepuasan pelanggan akan meningkat. Sehingga pelanggan yang pernah berkunjung dan menikmati makanan dan minuman di salah satu dari sepuluh (10) tempat makan masakan khas Jawa di Surabaya setuju bahwa restoran makanan khas Jawa menampilkan kualitas lingkungan fisik yang manarik dapat meningkatkan kepuasan pelanggan yang berukunjung dan menikmati makanan di tempat makan masakan khas Jawa di Surabaya.

Bowen dan shoemaker (1998) dalam Jalivand et al., (2017) menyatakan rasa senang pelanggan untuk merekomendasikan berasal dari nilai pengalaman konsumsi dimana pelanggan cenderung mengekspresikan pendapat dengan merekomendasikan pengalaman pelanggan kepada pelanggan lain, Dalam hal ini pelanggan yang pernah berkunjung dan menikmati makanan dan minuman di salah satu dari sepuluh (10) tempat makan masakan khas Jawa di Surabaya setuju bahwa kepuasan yang didapatkan pelanggan dapat mengembangkan keinginan untuk mengatakan hal-hal positif tentang restoran 
makanan khas Jawa serta adanya keinginan pelanggan untuk merekomendasikan salah satu dari (10) tempat makan masakan khas Jawa di Surabaya kepada pelanggan lain.

Jalivand Et al.,(2017) menyimpulkan bahwa interaksi pribadi dengan pelanggan merupakan salah satu elemen terpenting selain produk dan layanan di industri restoran, interaksi ini akan menciptakan nilai kepercayaan, kepuasan, kalkulatif, emosional dan komitmen serta memungkinkan pelanggan melakukan pemasaran WOM. Sehingga pelanggan yang pernah berkunjung dan menikmati makanan dan minuman di salah satu dari sepuluh (10) tempat makan masakan khas Jawa di Surabaya setuju bahwa kualitas interaksi yang baik, melayani pelanggan dengan ramah dan memiliki respon yang cepat dalam memenuhi keinginan pelanggan dapat terpenuhi, dimana karyawan atau pelayan sebagai front office yang berinteraksi secara langsung dengan pelanggan dapat meningkatkan kepuasan pelanggan.

Rust dan Oliver (1994) dalam Jalivand et al., (2017) nilai yang dirasakan pelanggan akan muncul dari hasil evaluasi antara manfaat (input) yang didapat dengan biaya (output) yang dikorbankan untuk mendapatkan produk atau layanan yang ditawarkan. Petterson dan Spreng (1997); Enggert dan Ulega (2002) dalam Jackie (2004) menyatakan nilai yang dirasakan dianggap sebagai nilai penentu dalam kepuasan pelanggan. Semakin banyak pelanggan merasakan kualitas layanan melebihi biaya yang didapatkan, maka semakin tinggi persepsi terhadap nilai layanan yang dapat menghasilkan kepuasan yang lebih besar, selain itu nilai yang dirasakan juga menunjukkan dampak yang kuat dan signifikan terhadap kepuasan pelanggan yang dapat mempengaruhi pelanggan untuk melakukan niat pembelian berulang.

Hubungan pembeli dan penjual dalam konteks offline menunjukkan bahwa kepuasan memiliki efek positif pada kepercayaan, alasannya adalah pengalaman memuaskan pelanggan menjadikan sumber kepercayaan bagi pelanggan tentang perusahaan, Garbaniro dan Johnson (1999) dalam Dabholkar dan Sheng (2012). Temuan lain juga menyatakan semakin tinggi kepuasan pembeli dengan pemasok, semakin besar kepercayaan pembeli mempercayai pemasok.

Hasil dari uji hipotesis ini didukung oleh hasil dari penelitian yang dilakukan oleh Dev dan Han (2011) dimana hasil dari penelitian tersebut menghasilkan variabel satisfaction tidak memiliki pengaruh terhadap variabel Commitment. Dev dan Han (2011) pada temuannya menyatakan bahwa kepercayaan dan komponen kualitas hubungan merupakan mediator yang sempurna untuk mempengaruhi nilai kepuasan pelanggan. Ok et al., (2005) dalam Dev dan Han (2011) 
menambahkan komitmen yang merupakan komponen kualitas hubungan lain memiliki peran sebagai mediator terhadap nilai kepercayaan pada niat perilaku pelanggan. Bowen dan Shoemaker (1998) dalam Ercis et al., (2012) menyatakan bahwa kepuasan saja bukan merupakan faktor yang cukup untuk mengukur komitmen dan kepuasan pelanggan dalam menciptakan pelanggan yang loyal.

Bellseter dan Zelman (2001) dalam Jalivand et al., (2017) menemukan bahwa kepercayaan terhadap merek memiliki pengaruh secara langsung terhadap komitmen pelanggan serta secara tidak langsung dapat mempengaruhi tingkat kestabilan harga. Casalo et al., (2007) dalam Sahagun et al., (2014) menyatakan kepuasan dan kepercayaan memiliki hubungan positif dengan komitmen. Garbirano dan Johnson (1999) dalam Sahagun et al., (2014) menambahkan ketika salah satu pihak rentan maka hasil yang didapat tidak pasti, maka dari itu komitmen hanya akan berposisi ketika kontrol atas resiko, sehingga kontrol semacam ini ditawarkan melalui kepercayaan. Moorman et al., (1992) dalam Sahagun et al., (2014) mengatakan tingkatan kepercayaan yang lebih tinggi dapat meningkatkan komitmen pelanggan.

Hasil dari uji hipotesis ini didukung oleh hasil dari penelitian yang dilakukan oleh Han dan Ryu (2012) dimana hasil dari penelitian tersebut menghasilkan variabel
Trust tidak memiliki pengaruh terhadap variabel Word of Mouth. Han dan Ryu (2012) menyatakan bahwa tingkat nonmonetary switching cost tidak signifikan berpengaruh pada niat nonmonetary switching cost, karena tingkat kepercayaan dan komitmen pelanggan dalam konteks restoran full service tidak bergantung pada adanya kedua jenis switching cost sehingga operator restoran harus dapat mengembangkan kepercayaan dan komitmen pelanggan.

Hasil penelitian ini sejalan dengan penelitian yang dilakukan oleh Sumedi et al., (2015) dimana pada penelitiannya menyebutkan terdapat tiga komponen dalam variabel komitmen pelaggan yaitu, affective, calculative dan normative yang dapat mencerminkan motivasi pelanggan untuk melanjutkan hubungan (Cater dan Zabkar, 2009). Komitmen afektif merupakan komitmen hubungan pelanggan dengan penyedia layanan yang disebabkan oleh ikatan emosional. Ikatan emosional ini muncul karena perasaan positif, gembira dan kesetaraan dari hubungan yang dimiliki antara pelangggan dan penyedia layanan. Semakin tinggi komitmen afektif pelanggan pada penyedia layanan semakin tinggi ikatan emosional pelanggan dengan penyedia layanan.

Komitmen kalkulatif merupakan komitmen pelanggan yang didasari oleh pertimbangan ekonomi, yaitu perhitungan untung dan rugi ketika mempertahaknan 
hubungan atau memutuskan hubungan dengan penyedia layanan. Komitmen kalkulatif muncul karena pelanggan menilai hubungan dengan penyedia layanan menggunakan perspektif penilaian rasional daripada emosional (Cater dan Zakbar,2009 dalam Sumedi et al., 2015).

Komitmen normatif merupakan komitmen yang berkaitan dengan norma sosial, moral, dan kewajiban pada pihak lain. Pelanggan yang memiliki komitmen normatif bisa memiliki perasaan bersalah jika pelanggan memilih untuk memutuskan hubungan dengan penyedia layanan. Oleh karena itu pelanggan yang memiliki komitmen normatif menunjukkan tingkat komitmen pelanggan untuk tetap berhubunga dengan penyedia layanan berdasarkan perasaan kewajiban untuk melakukannya (Cater dan Zakbar,2009 dalam Sumedi et al., 2015)

Hasil dari penelitian Sumedi et al., (2015) menunjukkan jika hipotesis penelitian pada variabel komitmen afektif terhadap Word of Mouth diterima, sedangkan hipotisis pada variabel komitmen kalkulatif dan normatif terhadap Word of Mouth ditolak pada konteks industri layanan bank Syariah. Dalam hal ini memunkinkan jika pelanggan restoran makanan khas Jawa sudah memenuhi komitmen secara afektif dimana pelanggan sudah memiliki ikatan emosional dengan salah satu dari kesepuluh tempat makan masakan khas Jawa di Surabaya hal ini dapat dibuktikan dengan hasil kuseioner yaitu pelanggan telah mengunjungi restoran sebanyak minimal dua kali dalam enam bulan terakhir.

Komitmen pelanggan secara normatif tidak ada larangan secara norma sosial atau norma agama yang melarang pelanggan untuk makan dan minum di salah satu dari kesepuluh tempat makan masakan khas Jawa di Surabaya. namun hasil yang dapat mempengaruhi komitmen pelanggan dengan Word of Mouth adalah komitmen secara kalkulatif dimana pelanggan bisa saja mengganti pilihan restoran lain, mengingat jika pelanggan bisa melihat masih terdapat alternatif lain dengan biaya yang lebih rendah untuk mekan dengan menu yang sama di tempat lain. Sehinggan pelanggan tidak merasa dipaksa untuk memiliki hubungan dengan restoran yang berbasis ekonomi.

\section{KESIMPULAN}

Hasil dari peneltian ini menunjukkan bahwa food quality memiliki pegaruh positif terhadap satisfaction. Dalam hal ini dapat dinyatakan bahwa tempat makan masakan khas Jawa di Surabaya telah memberikan kualitas makanan sesuai dengan keinginan dan kebutuhan pelanggan yang meliputi rasa makanan yang enak, suhu makanan yang hangat, memiliki tampilan yang menarik dan menggunakan bahan baku segar dapat meningkatkan kepuasan 
pelanggan yang menikmati makanan ditempat. Hasil dari physical environment quality juga menunjukkan bahwa memiliki hubungan positif terhadap satisfaction. Dapat dinyatakan bahwa tempat makan masakan khas Jawa di Surabaya dapat memiliki area makan yang nyaman, pencahayaan yang sesuai dan peralatan makan yang bersih telah terpenuhi, sehingga tingkat kepeuasan pelanggan yang berkunjung dapat terus meningkat.

Hasil dari penelitian menunjukkan bahwa personal interaction quality memiliki hubungan positif terhadap satisfaction. Dapat dinyatakan bahwa tempat makan masakan khas Jawa di Surabaya antara pelayan restoran dan pelanggan menjalin kualitas hubungan komunikasi atau interaksi yang baik. Dalam hal ini pelanggan telah menilai bahwa pelayan restoran telah memberikan pelayanan yang ramah serta pelayan dapat merespon dengan cepat keingianan pelanggan dengan baik. Sehingga tingkat kepuasan yang dirasakan melalui interaksi pelayan restoran dapat terus meningkat. Selain itu hasil penelitian juga menemukan perceived value memiliki hubungan yang positif terhadap satisfaction. Dapat dinyatakan bahwa pelanggan yang berkunjung ke tempat makan masakan khas Jawa di Surabaya menilai bahwa harga makanan yang ditawarkan, pelayanan yang diberikan dan pengalaman yang ditawarkan telah sesuai dengan keinginan pelanggan.
Sehingga dalam hal ini semakin tinggi nilai yang dirasakan pelanggan maka semakin tinggi juga tingkat kepuasan pelanggan.

Hasil dari penelitian ini menunjukkan bahwa satisfaction memiliki pengaruh positif terhadap word of mouth intentions. Dalam hal ini dapat dinyatakan bahwa tingkat kepuasan pelanggan yang tinggi dapat mempengaruhi perilaku keinginan pelanggan untuk memeberikan rekomendasi kepada pelanggan lain untuk mengunjungi tempat makan masakan khas Jawa di Surabaya. Selain itu penelitian ini juga menunjukkan satisfaction memiliki pengaruh positif terhadap trust. Dapat dinyatakan bahwa tingkat kepuasan pelanggan ketika berkunjung ke tempat makan masakan khas Jawa di Surabaya dapat meningkatkan kepercayaan pelanggan terhadap restoran yang dikunjungi.

Namun hasil yang berbeda dapat ditunjukkan pada penelitian ini bahwa satisfaction tidak memiliki pengaruh secara langsung terhadap commitment. Hai ini dimungkinkan karena terdapat faktor lain yang perlu diperhatikan yaitu terdapat alternatif atau pilihan lain yang menyajikan produk atau layanan yang sama namun dengan harga yang ditawarkan lebih murah, namun tetap bisa memenuhi kepuasan pelanggan, sehingga hal ini lah yang bisa menyebabkan kepuasan pelanggan terhadap restoran makanan khas jawa tidak akan selalu bisa membentuk komitmen pelanggan 
ke salah satu dari sepuluh restoran khas jawa di Surabaya. Konsumen tidak secara rutin mengkonsumsi makanan khas jawa, sehingga diperlukan variasi makanan yang disantap setiap hari

Hasil lain juga menunjukkan bahwa trust dan commitment tidak memiliki pengaruh secara langsung terhadap word of mouth intention. Dalam variabel trust, hal ini dimungkinkan karena kurangnya peningkatan kinerja interaksi yang dapat berkonstribusi untuk membangun ikatan sosial antara karyawan layanan dengan pelanggan, dan meningkatkan kepercayaan pelanggan. Selain itu perlunya menjaga hubungan antar pelanggan dan pelayan dapat meningkatkan niat pelanggan untuk merekomendasikan dan menyebarkan word of mouth positif. Terkait variabel commitment, dalam hal ini dimungkinkan pengaruh komitmen yang didasarkan pada motivasi ekonomi tidak berkorelasi dengan word of mouth, selain itu pelanggan tempat makan masakan khas Jawa di Surabaya melihat bahwa terdapat alternatif layanan lain dengan biaya switching yang rendah.

\section{IMPLIKASI PENELITIAN}

Hasil penelitian menemukan bahwa pelanggan kuliner Jawa di Surabaya menilai kepuasan bukan penilaian utama dalam membentuk komitmen untuk kembali menikmati makanan yang disajikan. Pelaku usaha perlu mencari dan mengembangkan hal-hal baru dari aspek lain seperti mempercantik interior dan eksterior bangunan atau memperbanyak variasi makanan serta meningkatkan pelayanan dan hal-hal kecil seperti kebersihan. Dalam bisnis restoran perlu dikembangkan nilai lebih yang tidak dimiliki pesaing. Hal ini menyulitkan pelanggan untuk mencari alternatif lain.

\section{DAFTAR PUSTAKA}

Choi, Beom Joon and Kim, Hyun Sik., 2012. "The Impact of outcome Quality, Interaction Quality, Peer to Peer Quality on Customer Satisfaction With a Hospital Service". Journal of Health Care Quality

Fang, Yu-Hui, Chao-Min Chiu dan Eric T.G. Wang. 2011. Understanding Customers Satisfaction and Repurchase Intentions. Journal of Internet Research, 21 (4), pp. 479-503.

Hair, J.F., et al. (2010). Multivariate Data Analysis. (7th edition). New Jersey : Pearson Education Inc.

Jalilvand, M. R., Salimipour, S., Elyasi, M., \& Mohammadi, M. (2017). Factors influencina word of mouth behaviour in the restaurant industry. Marketing Intelligence \& Planning, 35(1), 81110.

Kotler, P. and K. Keller. (2012). Marketing Management, Fourteenth Edition, Pearson Education Ltd. 
Moorman, C., Deshpande', R. and Zaltman, G. (1992), Relationship Between Providers and Users of Market Research: The Role of Personal Trust, Marketing Science Institute, Cambridge, MA.

Mowen, Jhon C dan Minor, Michael. 2002. Perilaku Konsumen. Penerbit Erlangga. Jakarta.

Namin, A. (2017). Revisiting customers' perception of service quality in fast food restaurants. Journal of Retailing and Consumer Services, 34, 70-81.

Namkung, Y. and Jang, S. (2007), "Does food quality really matter in restaurant? Its impact on customer satisfaction and behavioral intentions", Journal of Hospitality and Tourism Research, Vol. 31 No. 3.

Purnasari, H., dan Yuliando, H. (2015). 'How Relationship Quality on Customer Commitment Influences Positive e-WOM”. Agriculture and Agricultural Science Procedia, 3, 149-153.

Ribbink, D., Van Riel, A.C.R., Liljander, V. \& Streukens, S. (2004). "Comfort your online customer: quality, trust and loyalty on the internet". Managing Service Quality, 14.

Ryu, K. and Han, H. (2012), "Influence of the quality of food, service, and physical environment on customer satisfaction in quick-casual restaurants: moderating role of perceived price", Journal of Hospitality \& Tourism Research, Vol. 34 No. 3.

Wirtz Jochen and Chew Patricia Yp, 2002, "The Effect Of Oncentives, Deal Pronesss, Satisfaction And Tie Strenght On Word Of Mouth Behavior", international journal of service industry management, Vol. 13 No. 2, pp.141-162

Sekaran. U. dan R. Bougie, 2010, Research Methods For Business, Fifth Edition, A Jhon Wiley and Sons Ltd.

Sugiyono, 2013, Statistika untuk Penelitian, Bandung, Alfabeta.

Turmudi dan Sri Harini. 2008. Metode Statistika Pendekatan Teoritis dan Aplikatif. Malang: UIN-Malang Press.

Zineldin, M, Johannisson, B. and Dandridge, T. 1997. Strategic Relationship Management: a Multi Dimensional Perspective. Almqvist \& Wiksell International. 


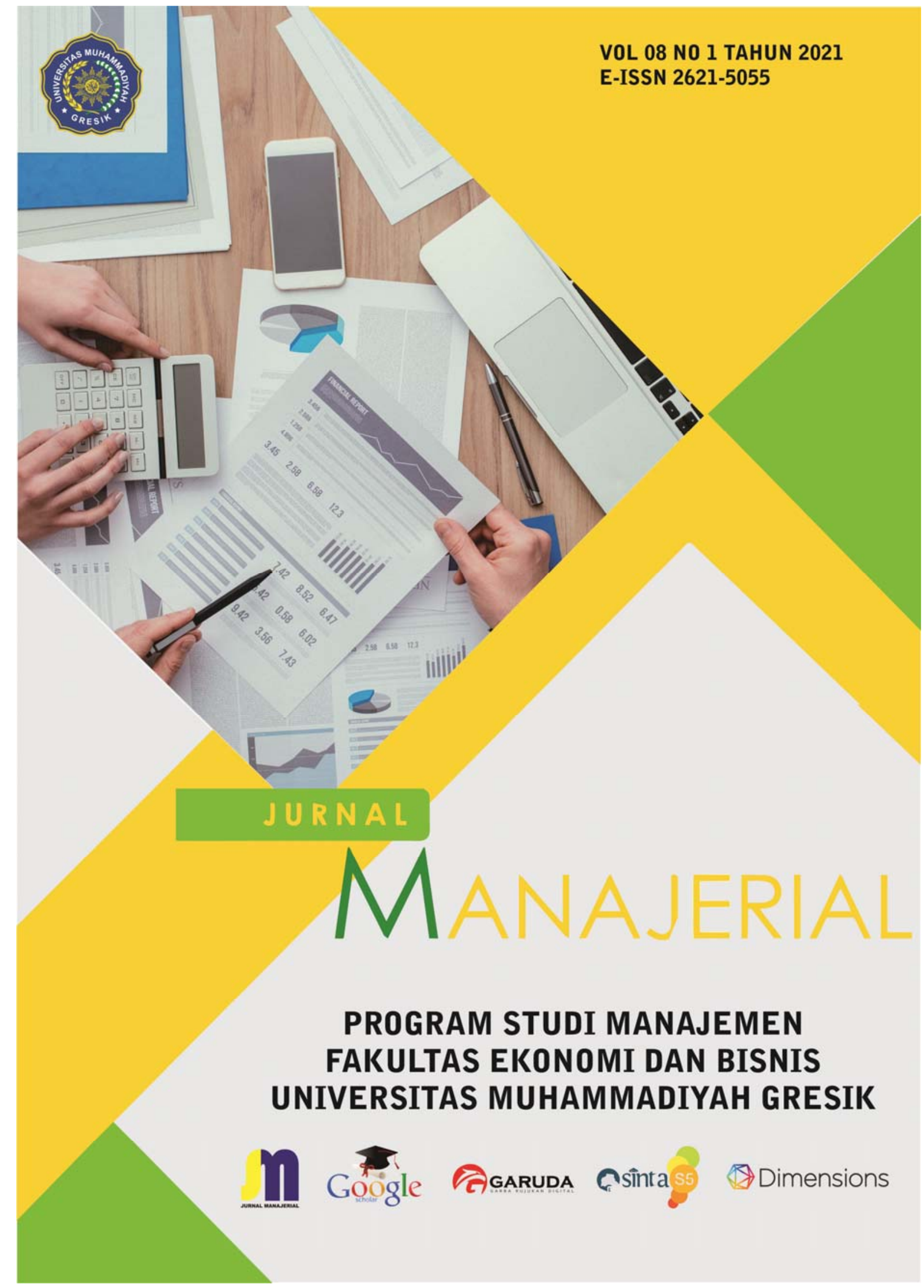


1. Manaugral

Current Archives About -

\section{Editorial Board}

Editor in Chief :

Maulidyah Amalina Rizgi, SE., MM - Universitas Muhammadiyah Gresik

ID Sinta : 6043324

ID Scopus: 57216156032

\section{Editors:}

1. Abi Hanif Dzulquarnain, S.KM. M.SM - Universitas Muhammadiyah Gresik ID SINTA : 6710021

2. Anita Handayani, SE. M.SM - Universitas Muhammadiyah Gresik

ID SINTA : 6010912

ID Scopus : 57216149829

3. Abdurahman Faris I.H. SE, M.SM - Universitas Muhammadiyah Gresik ID SINTA : 6004984

ID Scopus : 57216160386 
Home / Archives / Voi 8 No 01 [2021]: Jurnal Manajerial

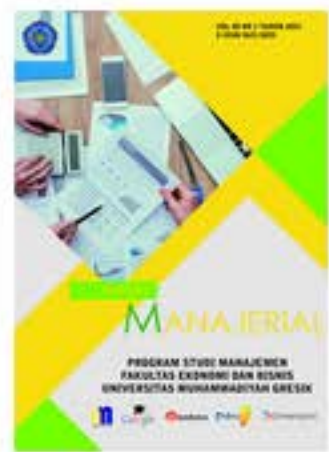

DOI: http://dx.doi.org/10.30587/manajerial.v8i01

Published: 2021-01-19

\section{Articles}

Foreign Ownership Effect to Stock Market Liquidity in Indonesia

Annisa Yasmin

Q PDF

Pengaruh Disiplin Kerja Terhadap Kinerja Karyawan PT. Perkebunan Nusantara XIII Pabrik Minyak Sawit Paser Belengkong

Amir Hamzah, Wahyudi Wahyudi, Eliana Eliana

国 pdf

Faktor-Faktor Yang Mempengaruhi Perilaku Word Of Mouth Intention Pelanggan PadaTempat Makan Masakan Khas Jawa Di Surabaya

Nurfathan Hasbiy Purwanto, Siti Rahayu, Ema Andajani

因 pdf

Determinan Individu Mengadopsi Layanan E-Payment (Studi Pada Millenials Di Kabupaten Gresik) Marisya Mahdia Khoirina, alfina alfina, Hans Febrianto Setyo

Pengaruh Karakteristik Individu Dan Leadership, Terhadap Kinerja Organisasi Dengan Teamwork Sebagai Variabel Intervening Pada Puskesmas Terakreditasi Paripurna Di Kabupaten Pasuruan

Mira Kurniawati, Lidia Andiani, Hanif Mauludin

圆 PDF

Analisis Strategi Positioning Produk Berdasarkan Persepsi Konsumen Pada Industri Batik Di Jawa Timur Kristiningsih Kristiningsih, Lestari Lestari, Wiwik Herawati

R PDF

Formulasi Strategi Ukm jilbab Azky Collection Untuk Meningkatkann Daya Saing Di Masa Pandemi Covid-19 Suaibatul Aslamiyah

\& pdf 